\title{
COVID-19 lockdown and students' changing perceptions of place: A participatory mapping study in South Africa
}

\author{
Kgothatso Langa, Nerhene Davis, Serena Coetzee * \\ ${ }^{a}$ Department of Geography, Geoinformatics and Meteorology, University of Pretoria, Pretoria, South Africa, \\ u17230447@tuks.co.za,\{nerhene.davis, serena.coetzee\}@up.ac.za \\ * Corresponding author
}

Keywords: participatory mapping, sense of place, COVID-19 lockdown, students, South Africa

\begin{abstract}
:
Sense of place refers to the relationship that people have with a place, and the meanings and values they attach to a place. Our sense of place influences our wellbeing, interaction with places, and the value that we attach to a place. Conversely, people make a place; without them, a place is just an empty space. The COVID-19 pandemic has impacted people's sense of place because the concept of a safe space changed, and restrictions were imposed on mobility. Students were especially hard hit because they are at the stage of their life where they like to go out in groups for entertainment and socializing. We asked ourselves how the COVID-19 lockdown had impacted students' sense of place on our campus and its surroundings.
\end{abstract}

On 31 December 2019, the novel coronavirus disease (COVID- 19) was first reported to the World Health Organization (WHO) following a cluster of cases in Wuhan, China (WHO, 2021). The first COVID-19 case in South Africa was reported on the 5th of March 2020 after a group of ten people returned from a trip to Italy a few days earlier. The government officially declared a national state of disaster on 15 March (Wiysonge, 2020). On 23 March, President Cyril Ramaphosa announced a three-week nationwide lockdown (level 5) starting at midnight on 26 March, imposing severe restrictions on travel and movement and supported by the South African National Defence Force (South African Department of Health, 2021). In response to the lockdown, the University of Pretoria suspended all contact classes and events on campus from 16 March until mid-April (Kupe, 2020) and students were instructed to vacate residences within 48 to 72 hours. Only international students and a small number of local students were allowed to stay (TuksRes Management, 2020).

Due to the lockdown, places that were once teeming with people, like the Hatfield campus and its surroundings, were deserted. Restaurants, bars, clubs, cinemas and fitness centres were closed. Alcohol and cigarette sales were banned. Concerts, sporting events, religious, cultural and social gatherings were not be allowed. Gradually, restrictions were eased as lockdown levels were lowered to level 4 on 1 May, level 3 on 1 June, level 2 on 17 August and level 1 on 21 September 2020 respectively (South African Department of Health, 2020a, 2020b, 2020c, 2020d). Online classes at the University of Pretoria resumed on 4 May (Panyane, 2020) and by level 2, residences could be filled up to $66 \%$ capacity at the start of the second semester (Mosia, 2020). It is anticipated that students' sense of place changed because of the lockdown. Their perceptions of places before and after the lockdown are likely to have changed. This study aims to understand the impact of the COVID-19 lockdown on students' perceptions of places on the Hatfield campus of the University of Pretoria (South Africa) and its surroundings. Specifically, we focus on identifying the 'where' of places perceived as fun, safe, stressful, and/or relaxing, and whether these connotations changed between 16 March and when students returned to campus later in the year.

The concept, sense of place, has been explored in various disciplines using different methods and approaches. As a result, it is challenging to narrow down a single definition of the concept. Several terms are used interchangeably to describe it (Nelson et.al, 2020), including place attachment, place meaning, place identity and place dependence. A positive emotional bond that a person has with their environment is called place attachment (Altman \& Louw 1992). Feelings that an individual has about a place and the connection to that place that defines who they are is known as place identity (Brown et al., 2015). Place dependence refers to how reliant an individual is on a certain place (Jorgenson \& Stedman 2006). According to Relph (1976), "place is a space imbued with meanings" and Žlender et al. (2020) state that "sense of place is defined as a unidimensional concept that is made up of three parts: emotional, cognitive and functional responses to a particular place". However, the majority of studies consider sense of place to be a multidimensional concept (Jorgensen \& Stedman, 2001; Agyekum et al., 2019; Nelson et al., 2020), e.g., Jorgenson \& Stedman (2001) consider place attachment to be a two-dimensional concept consisting of place identity and place dependence. In this study we focussed on sense of place as the meanings and values that students attach to places on the Hatfield campus of the University of Pretoria and its surroundings.

Through semi-structured interviews and participatory mapping, we investigated the changing sense of place of University of Pretoria students who live close to the Hatfield campus. Participatory mapping involves members of a community and allows them to express and represent themselves by the use of maps (Foundation, 2020). Three groups of students were recruited via email: one group resides in official university residences and were forced to leave Hatfield, while the other two groups live in private accommodation, some of them stayed in Hatfield during the 
lockdown, others returned to their parents. Students in private accommodations were not forced to vacate Hatfield, and their perceptions could there be different from those who were forced to leave. Each participant was given two maps of Hatfield and markers in four colours. They were asked to indicate areas on the map associated with each of the four categories - fun, safe, stressful, and relaxing. They marked the respective areas for the pre-lockdown context (before 16 March) on the first map, and on the second map the respective areas for their first return to Hatfield. Once a participant completed marking the two maps, a semi-structured interview was conducted to understand why they marked the maps in a specific way.

The results were spatially analysed to determine if and how the 'where' of fun, safe, stressful, and/or relaxing was impacted by the COVID-19 lockdown. Understanding students' changing perceptions of the Hatfield campus and its surroundings can assist the university with planning for a post-COVID-19 life on campus.

\section{References}

Agyekum, B. and Newbold, K. (2019). Sense of place and mental wellness amongst African immigrants. Journal of Urbanism, 12(2), 188-202.

Altman, I. and Louw, S. (1992). Place attachment. New York: Plenum Press.

Brown, G., Raymond C. and Corcoran, J. (2015). Mapping and measuring place attachment. Applied Geography, 57, 42-53.

Foundation, R. (2020). Rainforest Foundation UK. https://www.mappingforrights.org/participatorymapping/ [Accessed 28 April 2021].

Jorgensen, B. and Stedman, R. (2001). Sense of place as an attitude: Lakeshore owners' attitudes toward their properties. Journal of Environmental Psychology, 21(3), 233-248.

Jorgensen, B. and Stedman, R., (2006). A comparative analysis of predictors of sense of place dimensions: Attachment to, dependence on, and identification with lakeshore properties. Journal of Environmental Management, 79(3), 316-327.

Kupe, T. (2020). UPDATE: Postponement of contact classes and rescheduling of academic calendar. University of Pretoria COVID19 Information, News, 16 March 2020. https://www.up.ac.za/coronavirusupdates/ news/post_2881150-update_postponementofcontact- classes-and-rescheduling-of-academic-calendar- [Accessed 16 June 2021].

Mosia, T. (2020). Student life post-COVID-19: 'Life on campus will continue to be resilient and adaptable to the challenges of this pandemic,' writes UP Vice-Principal. University of Pretoria COVID-19 Information, News, 3 August 2020. https://www.up.ac.za/coronavirusupdates/ news/post_2912793-student-life-post-covid-19- life-on-campus-will-continue-to-beresilient-andadaptable- to-the-challenges-of-this-pandemic-writes-upvice- principal [Accessed 16 June 2021]

Nelson, J., Ahn J. and Corley, E. (2020). Sense of place from the literature. Journal of Urbanism, 13(2), 236-261.

Panyane, M. (2020). Thousands of University of Pretoria students resume classes online. University of Pretoria COVID-19 Information, News, 4 May 2020. https://www.up.ac.za/coronavirusupdates/ news/post_2894002-thousands-of-universityofpretoria- students-resume-classes-online [Accessed 16 June 2021].

Relph, E. (1976). Place and Placelessness. Pion: London.

South African Department of Health (2020a). COVID-19 Online Resources \& News Portal. https://sacoronavirus.co.za/2020/09/30/statement-of-theminister- of-home-affairs-regarding-the-reopening-ofborders- and-servicesduring-alert-level-1/ [Accessed 17 June 2021].

South African Department of Health (2020b). COVID-19 Online Resources \& News Portal. https://sacoronavirus.co.za/2020/08/17/from-the-deskof- the-president-monday-17-august-2020/ [Accessed 17 June 2021].

South African Department of Health (2020c). COVID-19 Online Resources \& News Portal.https://sacoronavirus.co.za/2020/05/30/ministerfikile- mbalula-coronavirus-covid-19-level-3-lockdowntransport- measures/ [Accessed 17 June 2021].

South African Department of Health (2020d). COVID-19 Online Resources \& News Portal. https://sacoronavirus.co.za/2020/04/23/statement-bypresident- cyril-ramaphosa-on-south-africas-response-tothe- coronaviruspandemic-union-buildings-tshwane/ [Accessed 17 June 2021].

South African Department of Health (2021). COVID-19 Online Resources \& News Portal. https://sacoronavirus.co.za [Accessed 16 June 2021].

TuksRes Management (2020). Closure of residences in view of the coronavirus COVID-19. University of Pretoria COVID-19 Information, News, 18 March 2020. https://www.up.ac.za/coronavirusupdates/ news/post_2881757-closure-of-residences-inviewof-the-coronavirus-covid-19- [Accessed 16 June 2021].

WHO (World Health Organisation) (2021). Q\&As on COVID-19 and related health topics. https://www.who.int/emergencies/diseases/novelcoronavirus- 2019/question-and-answers-hub [Accessed 16 June 2021].

Wiysonge, C. S. (2020). Think Global Health. https://www.thinkglobalhealth.org/article/south-africaswar- covid-19 [Accessed 11 April 2021].

Žlender, V. and Gemin, S. (2020), Testing urban dwellers' sense of place towards leisure and recreational peri-urban green open spaces in two European cities. Cities, 98, DOI:10.1016/j.cities.2019.102579. 